Spring 2000

\title{
Ruling Sexuality: The Political Legitimacy of Isabel of Castile
}

Elizabeth Lehfeldt

Cleveland State University, e.lehfeldt@csuohio.edu

Follow this and additional works at: https://engagedscholarship.csuohio.edu/clhist_facpub

How does access to this work benefit you? Let us know!

\section{Publisher's Statement}

(C) 2000 by University of Chicago Press. Available on publisher's site at http://www.jstor.org/ stable/2901532.

\section{Original Citation}

Elizabeth A. Lehfeldt, "Ruling Sexuality: The Political Legitimacy of Isabel of Castile," Renaissance Quarterly 53 no. 1 (2000): 31-56.

\section{Repository Citation}

Lehfeldt, Elizabeth, "Ruling Sexuality: The Political Legitimacy of Isabel of Castile" (2000). History Faculty

Publications. 7.

https://engagedscholarship.csuohio.edu/clhist_facpub/7

This Article is brought to you for free and open access by the History Department at EngagedScholarship@CSU. It has been accepted for inclusion in History Faculty Publications by an authorized administrator of EngagedScholarship@CSU. For more information, please contact library.es@csuohio.edu. 


\title{
Ruling Sexuality: \\ The Political Legitimacy of Isabel of Castile*
}

\author{
by Elizabeth A. LehfeldT
}

This article examines the gendered construction of power during the reign of Isabel of Castile (1474-1504). The construction of her political legitimacy was based on her manipulation of her gender and sexuality intended to contrast with the perceived shortcomings of her brother, Enrique IV. Enrique's critics had impugned his sexuality and attacked his inability to deliver Spain into a golden age. By aligning Isabel with sexually chaste models and emphasizing her ability to redeem Spain both because of and despite her gender, Isabel's partisans crafted an image that allowed her to transcend the misogynist tropes that attacked female rule.

R ecent scholarship has devoted intense analysis and scrutiny to the reigns Rof female rulers of the early-modern period. ${ }^{1}$ No longer the subject only of catalogs of "great women" or biographies, these treatments have also included sustained explorations of the exercise of female power from within the confines of a patriarchal and often overtly misogynist system. Curiously absent from many of these discussions, however, is the woman who was perhaps early-modern Europe's first female monarch, Isabel of Castile (who ruled from 1474 until 1504). This is not because she needs to be rescued from historical obscurity. The reign of Isabel and Ferdinand, her husband, has been consistently cited by political historians of the period as a significant chapter in understanding the late-fifteenth century emergence and consolidation of the "new monarchies." Yet this interpretation obscures the fundamental nature of Isabel's tenure on the throne of Castile. Ferdinand was accorded power, but much of it was confined to the realm of Aragon. $\mathrm{He}$ was mostly regarded as a king-consort in Castile, leaving Isabel with significant power in this vast and populous territory. Spanish-language scholarship, not surprisingly, has been quick to recognize the significance of her rule. Yet much of this has gravitated towards a hagiographic treatment of its subject. ${ }^{2}$

*Earlier versions of this article were presented at the February 1996 meeting of the Ohio State University Center for Medieval and Renaissance Studies and a meeting of the Cleveland Renaissance/Early Modern Seminar in February of 1997. I thank the participants at each for their comments and suggestions. I am indebted to the careful reading and comments of David C. Spaeder and the readers for Renaissance Quarterly. Any shortcomings and errors, however, are my own responsibility.

${ }^{1}$ See, for example, recent works by Levin, Hackett, and Fradenburg.

${ }^{2}$ This strain may have been inspired by the very serious campaign to have her canonized that stretched over the centuries following her death. This scholarship may also owe much of 
Other recent biographies have restored her to the canon of noteworthy powerful women of this era. These accounts, however, have included only tantalizingly brief considerations of the interplay of gender and power in a period when the presence of a female sovereign muddied the political waters. ${ }^{3}$ There were certainly those who reviled the prospect of female rule, and Isabel's rise to the throne was hotly contested on these and other grounds. Yet this should not suggest that Isabel, by virtue of her sex, was a permanently handicapped ruler. I contend instead that Isabel's political career reveals the "plasticity" of gender - which is to say that gender definitions are constantly being created and recreated. ${ }^{4}$ By crafting an image of her reign that frequently capitalized on the presumed shortcomings of the preceding rule of her half-brother, Enrique IV, Isabel's gender and sexuality and the potential redemptive power of each of these categories were constantly being redefined and refashioned.

At the time of the death of Enrique IV in 1474 , Spain ${ }^{5}$ was anxious for a strong ruler that would deliver them from years of court intrigue and turmoil. Dissatisfactions with Enrique's reign focused on numerous issues of his perceived ineffectual rule: his reported inability to produce an heir, distress over his less-than-definitive campaigns in Granada, and his too-friendly relations with Spain's religious minorities, the Jews and Muslims. The peninsula was desperate for a monarch who would rule with a firm and moral hand and deliver it from the religious and political presence of the Muslims (a wish felt even more keenly throughout Europe after the fall of Constantinople in 1453). Yet the monarch who stood on the thresh-

its adulatory tone to Isabel's own chroniclers, who, as other scholars have indicated, were unabashedly partisan in their accounts of Isabel's reign; see Phillips. For an argument regarding the significance of these chronicles in establishing Isabel's political legitimacy see below.

${ }^{3}$ The recent outstanding biography by Liss, for example, does address these issues, but the intersection of gender and politics is part of a largely narrative and chronological structure, and is rarely isolated as a target of separate analysis. This structure limits the ability to juxtapose the texts and issues that will be the subject of this article. Liss, in fact, has examined many of the texts that form the basis of my argument, but I do not always agree with her interpretation. For another very comprehensive and satisfactory biography see Azcona, 1964. For a fruitful examination of Isabel's epistolary works that analyzes the gendered constructions of Isabel's power see Weissberger, 1997. For an examination of the use of politically legitimizing symbols and ceremonies by Isabel and her Trastámara predecessors, see Ruiz.

${ }^{4}$ Fradenburg, 2.

${ }^{5}$ The use of "Spain" as an entity is admittedly problematic given the fractured nature of the peninsula during this time. Nonetheless, with the marriage of Isabel and Ferdinand the construct of a unified peninsula began to gain currency. The combination of their marriage unifying two large territories, Castile and Aragon, and their campaign against the Muslim kingdom of Granada seemed to portend such an eventuality. 
old of these demanding tasks was female. There was an ambiguous and limited tradition of female monarchical rule in the peninsula; most had acted as regents and many were a dim memory at best. ${ }^{6}$

And certainly the general European consensus on the question of female rule was to avoid it whenever possible. Women were fickle and weak. Women lacked such qualities as reason, courage, and strength that were so desirous in a monarch. Isabel's reign, then, rested on the horns of a dilemma. She was a much-heralded monarch who could right the wrongs of her predecessors. Yet she was female. Could Castile's redeemer come in the form of a woman? The answer was a qualified "yes" if Isabel was willing to acknowledge her shortcomings as a woman and to transcend these characterizations whenever possible.

Doing so would require careful manipulations of both Isabel's gender and sexuality. Enrique's rule provided an important object lesson in this regard. Many of the attacks on the shortcomings of his reign had focused on his sexuality. He was accused of both impotence and homosexuality. ${ }^{7}$ Both of these attacks stemmed from rumors that his daughter, Juana, had in fact been fathered by one of his courtiers. He was thus a cuckolded and effeminized ruler, ${ }^{8}$ whose wife had sought sexual satisfaction and procreation from one of his trusted advisors. He was further effeminized by his detractors for his military endeavors. In a culture that prized aggressive behavior as the central sign of manliness, ${ }^{9}$ the slow and incremental nature of his Granadan campaigns lacked the decisive victory that many Spaniards desired. Finally, his reliance on Jewish and Muslim advisors further compromised his masculine sexuality. ${ }^{10}$ As Louise Mirrer has persuasively argued, both of these groups were themselves effeminized in the literature of late-medieval Castile (47-80). Therefore, Enrique's close dealings with them compromised not only the integrity of Christianity, but the integrity of his maleness. The combined power of these effeminizing critiques constituted an attack on his monarchical power. The obvious misogynist attacks on female rule aside, it was not enough to be a male sovereign; that same sovereign's sexuality had to be beyond impunity. As an effeminized ruler he compromised the strength

${ }^{6}$ Among these were Elvira (966-975) who had acted as regent for her brother's son in León; Urraca (1109-1126), who inherited the thrones of Castile and León from her father; Berenguela, daughter of Alfonso VII (1158-1214) who had ruled briefly as queen of Castile; and Catalina of Lancaster (1390-1406) who was co-regent for her son, Juan II of Castile.

${ }^{7}$ For another examination of Enrique's impugned sexuality see Weissberger, 1999.

${ }^{8}$ Brandes, 90 .

${ }^{9}$ Mirrer, 47.

${ }^{10}$ Rather than laying definitive siege to the focal point of Muslim power, the city of Granada, Enrique fought rapid battles for smaller portions of territory. Phillips, 54-56. 
of and respect owed to the throne. As a female ruler Isabel had not only to confront her gender, but also her sexuality. In this instance, she and her advisors would emphasize the message of redemption. Her own sexuality would have to be properly channeled both to provide a contrast to the ineffectual rule of Enrique and to bring it into concert with Spain's larger campaigns for religious orthodoxy and Catholic integrity.

From the start, despite the handicaps of gender and sexuality, Isabel boldly asserted her monarchical power. Although she deferred to her brother Enrique during his lifetime, she moved smoothly to consolidate her power as sovereign monarch of Castile. She made this transition, in large part, without any of the mitigating effects that Ferdinand's presence might have conferred. The two had agreed to a series of capitulations after Enrique's death that left much of the administration and oversight of Castile to Isabel. ${ }^{11}$ Isabel held sole proprietorship of Castile and retained control of key appointments (treasurers, local judicial officials, and other officials). Even in instances where they both could make appointments, they could only come at her volition. Isabel also exerted substantial control over revenues. As a result of the agreement she gained control over a diverse, populous region that was coming into its own economically at the advent of her reign.

She was not hesitant to exercise this authority (even before it had been officially promulgated). ${ }^{12}$ In December of 1474 in Segovia, for example, after Enrique's death (and after performing the customary funerary and religious rites) in accordance with precedent, she announced her royal presence by presiding over a gathering in the city's main square. Afterwards the clergy and nobility who were present took an oath of allegiance to her and the news of her accession to the throne was publicly pronounced. She then rode in an elaborate procession followed by the attendant dignitaries. ${ }^{13}$ The significance of this ceremony taking place in Segovia should not be underestimated. Enrique had held title to the town and had a deep attachment to it. ${ }^{14}$

Isabel also revived a much older medieval tradition by having her procession preceded by a member of the nobility carrying a sword (rather than the scepter which was a more traditional representation of kingly power in

${ }^{11}$ Liss, 106-07.

${ }^{12}$ She had also been acting with royal authority before this ceremony, making grants to those loyal to her. See Phillips, 115.

${ }^{13}$ Liss, 98.

${ }^{14}$ See Phillips, 105. The city fell to rebel forces during the civil war between Enrique and the supporters of Enrique's half-brother and Isabel's brother, Alfonso. Enrique was willing to concede the mastership of the military Order of Santiago to his conniving advisor, Juan Pacheco, in order to have the city returned to him. 
Spain by this time).${ }^{15}$ Some raised objections to a woman processing with this symbol of political power before her, believing that this was the place of Ferdinand. One of her chroniclers, Diego de Valera, however, defended the action by admitting that normally this was not something that women should do, yet in this case Isabel was exempt from such dictates since "she was and is the sovereign 'señora"' of the kingdoms (4). Additionally, the events in Segovia provided a striking counter-point to the dethronement ceremony that the rebel noble faction opposing Enrique had performed when it broke with the king in $1465 .{ }^{16}$ In Avila the rebel leaders had placed a statue representing the king on a stage. The figure was accompanied by symbols of royal power: crown, scepter, and sword. One by one, the rebels denuded the "king" of these objects, symbolically stripping him of his office. In the final blow, the statue was kicked off its chair and Alfonso, Isabel's brother, (who died in 1468) was crowned. For Isabel to raise the most masculine of these symbols in the Segovia proceedings was a clear assertion of her royal authority.

Although oaths were also made to him as Isabel's legitimate husband, all of these acts were performed in the absence of Ferdinand who was in Aragon at the time. Conceivably, Isabel could have waited for him to join her. Yet knowing that the partisans of Enrique's daughter, Juana, were likely to rally their forces, she sensed the need to seize the moment and have herself declared queen.

Despite such ostentatious displays of her power, her political legitimacy was far from consolidated. A bitter civil war ensued with various noble factions advancing the cause of Juana (a daughter rumored to be the offspring of an illicit affair between Enrique's wife and one of his closest advisors, Beltrán de la Cueva ${ }^{17}$ against the claims of Isabel and her noble supporters. The campaign to establish Isabel's claims to the throne had actually begun even before she took the throne in the wake of Enrique's death. As early as around 1468 Isabel's partisans were laying the foundation for her later political claims. The Augustinian monastic, Martín de Córdoba, presented Isabel with an advice manual, Jardin de las nobles doncellas (Garden of Noble Maidens ). This manual, modeled after the popular genre of "mirrors for princes," had a curious twist. While its ostensible purpose was to justify and soften the blow of the seemingly inevitable rule of a female monarch (even if Isabel had not ascended to the throne, Enrique's only offspring at this point was, and

${ }^{15}$ This was also, of course, an undeniably male, phallic symbol.

${ }^{16}$ Phillips, 79.

${ }^{17}$ This rumor gave rise to the name by which this daughter is known to history: Juana la Beltraneja. 
would remain, female), the work nonetheless contained overt criticisms of female "nature" with corresponding advice for how a female ruler might overcome these womanly pitfalls and still manage to rule justly and effectively. The work has been regarded by recent scholars as a contribution to the pro-feminist debate of this period. ${ }^{18}$ For the purposes of examining Isabel's attempts to establish political power, the text is still a complex treatise on the subject of female rule. While its fundamental message and intent is positive - a woman can be an effective political leader - the argument that moves towards this conclusion is more tentative. While praised for some of women's admirable "natural" qualities, Isabel is also advised in this text to avoid certain female pitfalls and to overcome the shortcomings of her sex. Further, at the end of the text Isabel's relationship to any future husband is carefully outlined in a series of directives about the behavior of wives towards their husbands. The cautionary tone of the text would become emblematic of how even Isabel's supporters would lobby her case. A woman could rule, but only by acknowledging her shortcomings and by perhaps having checks (like a husband) on her power.

To give the text credit, it begins on an ambitious note. Its stated purpose is to argue against those that see misfortune in the rule of women. ${ }^{19}$ To make his point, Fray Martín emphasizes the positive qualities that women, by nature, possess. They are pious. They are obliging and attentive. And yet, as Martín is the first to reveal, women also have to discipline themselves to avoid certain character traits. Speaking of women's "less good qualities" (208) Martín labels them intemperate, obstinate, and changeable (209). Despite the fact that much of the text is an argument against the popular tropes of medieval misogyny, Martín himself invokes several of them in this statement. Female intemperance, he argues, results because women are endowed with less reason than men and are thus inclined to the passions of the flesh (210). He does hold out the hope that women can overcome some of their naturally disadvantageous qualities, like weakness and timidity (245).

Martín devotes the closing portions of the manual to a series of chapters containing directives about the proper role between wives and husbands. The first of these appears as part of a recounting of the lives of admirable women. In the third of these chapters he speaks of women who loved and

${ }^{18}$ See the comments of Surtz, 17 and Ornstein, 221-34. By "pro-feminist" these scholars mean to indicate "non-misogynist." In this their assessment is quite valuable; texts like Córdoba's lack the vitriolic misogynism of other treatises on women from the period. My only concern is that labeling these texts as "pro-feminist" may lead us to minimize the criticism of women that are contained in them.

${ }^{19}$ Córdoba, 136. Unless otherwise noted, all translations are mine. 
were faithful to their husbands. The eighth chapter outlines guidelines for conversation between wives and husbands. Perhaps these sections were intended to assuage dissatisfaction about the potential of a female ruler. Martín's expectation, as well as that of other Spaniards, was that Isabel would certainly not rule alone. As such, even if she sat on the throne of Castile, she would still be expected to be a good wife. This role would have required a certain docility and obedience that might have mitigated her capacity to control all authority, thereby placing it in more acceptable and male hands.

Martín's text, then, is a mixed bag. Its very intent and the genre to which it belongs, mirrors for princes, served to underscore the possibility of female rule in Spain. In answering to many misogynist sentiments it upheld Isabel's ability to govern in her own right. Yet the text also urges Isabel to transcend certain "natural" character traits. She is also asked to understand that she will inevitably take a husband and be required to submit to him, thereby perhaps compromising her own authority. Martín's lack of misogyny in a literary world amply populated by satirical and vicious attacks on women is noteworthy, but his justification of female rule is tempered by caveats that exhorted Isabel to confront the limits of her womanly nature.

Attempts to establish her legitimacy were still at stake and performed against the backdrop of the ongoing civil war that followed Enrique's death in 1475 when Isabel requested that the Jeronymite prior of the monastery of Santa María del Prado in Valladolid, Hernando de Talavera, ${ }^{20}$ make a copy of his sermon preached to the monks at Santa María during the Advent season. ${ }^{21}$ Talavera took this opportunity to re-fashion the sermon to contain political advice for this young female monarch who had only recently risen

${ }^{20}$ Talavera would continue from this point onward to exert a tremendous influence on the regin of Isabel. He would act as her confessor during the early years of her tenure on the throne. His religious career would also flourish under her patronage. He would ultimately rise to the position of Archbishop of Granada in the wake of the reconquest of 1492. Although Cardinal Francisco Ximénez de Cisneros has often been cited as having a profound impact on the joint fashioning of religious and political power under the Catholic Kings, Talavera should also be credited with shaping much of the combined political and religious legitimacy of Isabel in particular as will be demonstrated in various parts of this article. See Weissberger, 1997, for an examination of Isabel's relationship with him.

${ }^{21}$ The text of this sermon, "Collaçion muy provechosa de cómo se deuen renouar en las ánimas todos los fieles cristianos en el sancto tiempo del adviento . . .," as adapted for Isabel appears in Amador de los Rfos, 544-61; all references to Talavera appear in this edition. Liss has analyzed this sermon extensively as well, but focuses primarily on the "positive" messages that Talavera offers; see 121-26. I find the text to be less straightforward in its endorsement of female rule. In addition, I think that its original conception as a sermon for male monastics is a fundamental piece of determining its meaning for Isabel. 
to the throne of Castile. ${ }^{22}$ Employing the metaphorical figure of the eagle (the significance of which will be explained below), Talavera addressed the theme of renewal which he designated as appropriate to the liturgical season of Advent (545). Yet the text also seems implicitly to address a parallel renewal of perhaps even greater significance: the renovation of Spain. In raising the theme of renewal Talavera was implicitly recognizing the criticisms of Enrique's reign that had emerged even during his lifetime. Although they would receive more elaborate articulation in the later chronicles commissioned by Isabel and Ferdinand, these ranged from the familiar attacks on Enrique's sexuality to critiques of his campaigns in Granada as ineffectual and too limited. Two literary works penned during his reign represented a Castile that under Enrique's tutelage had fallen into a state of moral decay. ${ }^{23}$ Rescuing Spain from this legacy and from the disruption of the civil war that had erupted upon his death seemed to Spain's elite of critical importance. Although Talavera refrained from citing Enrique as the cause of Castile's need for renovation, his evocation of the theme of renewal is an implicit nod towards these currents of thought which, not surprisingly, were readily employed by Isabel's followers. Choosing the eagle as the fundamental image of this theme, Talavera moved to outline Isabel's identification with this symbol and her role in this unfolding drama of redemption. ${ }^{24}$

The eagle was, significantly, the symbol of Isabel's patron saint, John the Evangelist. The association with the eagle extended even further, to Isabel's father, Juan II. The image thus fostered strong links with his reign. Although Juan II did not have a reputation as a highly successful monarch, viewed in the historical perspective of the late-fifteenth century, it was at least more successful than that of Enrique. References to Juan also effectively bypassed the claims of Enrique's daughter, Juana, to the throne. The crown would descend first to Juan's children and not necessarily to his children's offspring, thereby countering the claim of Enrique's daughter to the throne. As a symbol shared by two prominent "Juans" - one with spiritual prestige, the other with dynastic prestige - the figure of the eagle resonated with both political and religious significance and hence, legitimacy. Finally, the gender of the word in Castilian (aguila) was also, conveniently, feminine. This combination of factors made it relatively easy for Talavera to establish a solid identification between Isabel and the animal that he called the "queen of the birds" (544).

\footnotetext{
${ }^{22}$ Although she and Ferdinand had been married in 1469, Isabel's recognition as queen of Castile did not begin until around 1474, after Enrique's death.

${ }^{23}$ These were the Coplas de Mingo Revulgo and Coplas del Provincial.

${ }^{24}$ In so doing, Talavera seems to have drawn on standard treatments of the attributes of the eagle in medieval bestiaries. See, for example, Baldwin; White.
} 
Having created this link, however, Talavera's sermon moved away from its emphasis on explicitly shoring up Isabel's legitimacy and turned instead to a discussion of the traits and characteristics of the eagle that made it such a potent symbol of renewal. Thus, the sermon's argument, designed to underscore Isabel's legitimacy, is one of association. Isabel had already been clearly identified with the eagle. The task that remained was to champion the qualities of this animal. Talavera identified nine chief characteristics or habits that distinguished its character both literally and metaphorically. ${ }^{25}$ As might be expected, the eagle is the embodiment of all the qualities of the strong ruler. In addition to being brave, it also possesses a sharp and penetrating sight/insight (vista). In many instances Talavera suggests that these qualities had been lacking in Castilian leadership and anticipates the later criticisms that Isabel's chroniclers launched against Enrique. It rules with firmness and justice, for example, inspiring a healthy balance of awe and fear. Here Talavera seems to be addressing the criticism that Enrique had allowed lawlessness to run rampant in the peninsula. ${ }^{26}$ Further, the eagle avoids idleness. Enrique was often denigrated for preferring to hunt in the forests of Segovia than tending to the business of government. ${ }^{27}$

In each of these nine sections Talavera first outlined why these were desirable characteristics for religious to emulate (the sermon had first been preached to the Jeronymite monks of Santa María del Prado). He then identified the need for a strong ruler to possess the same. This juxtaposition of the role of religious and the secular monarch is striking. Each represented one of the twin poles of the reform and regeneration of Castile in an age where religious and political legitimacy were never far removed from one another. Professed religious were entrusted with embodying piety and virtue as an example to others. If they did not adhere to the accepted code of morality and religious behavior, how could the rest of the populace be expected to do the same? The ruler, for his or her part, had also to be morally upright and to provide an example of strong leadership from which the people would take their cue. Here, too, the comparisons with Enrique's reign cannot be accidental; his immorality was often cited as the cause of the kingdom's decay and moral torpor. The coupling of religious and political responsibility

${ }^{25}$ The eagle is liberal; it is strong; it possesses a hot and dry complexion; it is brave and spirted; it is never idle; it makes its home on the highest peaks; it carefully protects its young; it teaches its young to fly; and it is capable of renewing itself in both body and spirit.

${ }^{26} \mathrm{See}$, for example, a letter of Fernando de Pulgar, one of Isabel's chroniclers, where he accused Enrique of negligence in his administration of justice which led to dissension and scandal. Pulgar, 1929, 78.

${ }^{27}$ In his glosses on the Coplas de Mingo Revulgo Pulgar, 1929, implied that Enrique had neglected the duties of government through his idleness (170). 
would reappear later in Isabel's reign as she sought the moral reform of Spain's religious (see below).

Despite its refashioning intended to legitimize Isabel's rise to the throne, the text is in some ways not unlike Córdoba's Jardin. Some ambivalences, linked to issues of gender, are embedded in the text of the sermon. When discussing the complexional/humoral temperament of the eagle, which he had previously identified as the "queen [emphasis mine] of the birds," for example, Talavera designated it as hot and dry, which according to late-medieval medical conceptions were decidedly male attributes (549). Ancient and medieval scientific discussions of the temperament of women defined them by nature as cold and moist. This conceptualization was agreed to account for a host of women's negative qualities. Thus, for Galen "the female is less perfect than the male for one, principal reason - because she is colder." ${ }^{28}$ Her moist composition, according to Albertus Magnus, provided a "natural" explanation for her inconstancy: "Woman's complexion is more humid than man's. [The nature] of the humid receives an impression easily but retains it poorly. The humid is readily mobile, and thus women are inconstant and always seeking something new." 29 Heat, on the other hand, was associated with positive traits such as courage, honesty, and physical and moral strength. According to Talavera himself this complexional balance was "better ... for intellectual operations" (549). Clearly, if women "naturally" lacked the humoral propensity for possessing these traits, female rulers operated at a distinct disadvantage. Woman's lack of heat, for example, contributed to her irrationality. Yet reason was a highly prized power in a ruler; it permitted a balanced rule that dispensed justice with authority and intelligence. Traits like courage and physical and moral strength were particularly required of Spanish leaders during this time as the Christian reconquest of the Moorish strongholds in southern Spain figured largely in Spain's plan for its own renewal. Where did this leave Isabel as a potential ruler? Although Talavera never said so explicitly, Isabel, in order to fulfill her identification with the eagle would have to transcend her fundamental female nature.

Striking a further note of ambivalence, the sermon also explicitly recognized that Ferdinand would play a role in the government of Castile. Early in the text Talavera addressed Ferdinand's position as Isabel's worthy husband (547). As such Talavera offered at the end of the sermon different models of behavior for male and female rulers. In a section entitled "Cómmo deuemos firmar nuestro pensamiento en las uidas y passyones de los grandes sanctos y cathólicos varones, para los remedar ..." (How we ought to fix our thought

${ }^{28}$ Quoted in Bullough, 492.

${ }^{29}$ Quoted in Cadden, 185. 
on the lives and passions of the great saints and Catholic men, in order to imitate them), he began by offering to "kings, princes, dukes, and marquises" biblical examples of right behavior. Noah is praised for his faith and obedience. Isaac is revered for his subjection and reverence (552). Joseph is to be admired for his chastity, loyalty, and prudence. Curiously, there is little mention in this section of war-like and forceful virtues (like those, for example, associated with the hot and dry temperament of the eagle). The emphasis is on more passive attributes. A recounting of important, but gentler, virtues may be intended to avoid attributing any "manly" features to Isabel. Even though this section was intended for male rulers, the text as a whole was given to her. Associations with warlike characteristics would have perhaps allied Isabel too closely with overtly aggressive traits which were at best an ambiguous means of communicating female strength. This focus may also reflect the original intention of the sermon; its original audience was male regular clergy who would have been encouraged to shun such aggressive action.

Where male leaders are offered these models, "queens, princesses, and all ladies great and small" (556) are encouraged to follow the example of Sarah's chastity, the Virgin Mary's humility, and the charity of Saint Martha. Thus although acknowledging Isabel's capacity to rule, the sermon demarcated a difference between male and female rulers who were instructed to follow different models in shaping their reign.

So while Talavera's Advent sermon did much to advance the cause of Isabel's political legitimacy it must also be read to contain ambivalences that undoubtedly reflected the tenor of the times. Isabel was the much longedfor monarch who could place Spain on the path to redemption. Yet she was still female and thus had to be regarded with caution and a certain amount of circumspection. Her legitimacy would rest in part on both a recognition and a subsequent rejection of her nature as a woman.

If Isabel's female nature was a potential liability, then it might be surprising to realize that her sexuality held some prospect of enhancing her political legitimacy. When held against the example of Enrique's alleged sexual failings and the resulting immorality and lack of leadership that these had occasioned, there was much in Isabel's sexuality that held the promise of strong rule and redemption. The goal, then, was to provide this contrast which would elevate Isabel's legitimacy. Much of this task fell to Isabel's chroniclers.

Though criticized by some modern historians for launching what amounted to a smear campaign against Enrique and his reign, ${ }^{30}$ Isabel's chroniclers responded to the political crisis that erupted after Enrique's death with the political savvy one would expect from those in the employ of

${ }^{30}$ Phillips, 1-16. 
the newly-ascendant queen. Whether or not the picture that these chroniclers drafted was historically accurate is beside the point in examining the creation of Isabel's political legitimacy. It is perception that matters in the game of politics and the late-fifteenth century was no different from the present day in this regard. Thus, Isabel's chroniclers set about the task of not simply denigrating Enrique's rule, but of offering as a dramatic counterpoint the redemptive power of Isabel's place on the Spanish throne.

Whether their tone was exaggerated for effect or more moderate, most of the chroniclers cited Enrique's impotence and the cuckolding that this had produced when his wife had supposedly conceived a daughter by her lover, Beltrán de la Cueva. The anonymous Crónica incompleta mentioned his rumored impotence and the difficulties this posed in his attempts to produce an heir (55). Fernando de Pulgar echoed these attacks and named Beltrán de la Cueva as Juana's undisputed father (1943, 1:5). Later in the chronicle Pulgar also recounted how many of the nobles who were critical of Enrique's governance had portrayed him as an effeminate man who had willfully given his wife over to Beltrán de la Cueva (12). Alonso de Palencia, who had been a supporter of Isabel's late brother, Alfonso, extended the charges to include immorality and decadence. ${ }^{31}$

In fact, Palencia's critique struck a critical note in the denigration of Enrique. Charges of an impugned sexuality and decadence were frequently used to question Enrique's ability to rule effectively. The Crónica incompleta made dire pronouncements characterizing the later period of Enrique's reign as a time when sinners had no shame and were in fact praised for their blatant wrongdoing (98). Diego de Valera echoed these sentiments and pointed to dramatic instances of Enrique's political and religious failings. He boldly asserted that Enrique's lack of leadership and punishment of crime had created a state of lawlessness in which men were robbed, churches were pillaged, and women were raped (5). In these three accusations Valera neatly summed up a complete breakdown of the social order. Everything Castilians held dear - property, sacred spaces, and female honor - had been violated.

This breakdown, however, extended to the spiritual order. Later in the chronicle Valera questioned Enrique's piety and religiosity. Enrique had frequently been criticized by his detractors for "excess favor for Muslims, Jews, and conversos [Jews who had converted to Christianity]." 32 The religious climate of medieval Spain was highly charged. The Muslims had been and continued to be the target of a vigilant reconquest campaign. Spanish Jews were terrorized (particularly from the late-fourteenth century onward) by

${ }^{31}$ Ibid., 3.

${ }^{32}$ Phillips, 81 . 
outbreaks of physical violence directed at them and their property and forced conversions. The position of each group in Spanish society was rarely fixed or secure. Though it is difficult to pinpoint its source or impetus, late-medieval Spain seems to have been seized by an increasing intolerance for both groups. Spanish kings had often regarded Muslim as "allies and trading partners," and not always wished to lay waste to their domains. ${ }^{33}$ One of Enrique's greatest failings in the eyes of the Spanish nobility whether motivated by greed for land or religious conviction - was his limited campaign against Granada. After recovering from a series of violent attacks on their communities in and around 1391, Spain's Jews enjoyed a brief respite before violence flared up again beginning around the mid-fifteenth century. These bursts of violence frequently resulted in conversions - both forced and voluntary. This, however, created a new and ambiguous category of "New Christians" or conversos. Conversos were often suspected of insincere conversions that resulted in their secretly practicing Judaism. A "new" Christian, additionally, could never be as good as an "old" Christian who could cite centuries of familial adherence to the faith.

Valera, in fact, capitalized on this tension in his account of the spiritual decline of Castile. Enrique's lack of devotion had led not only conversos, but also old Christians to turn from the Catholic faith (123). For Valera and others Enrique had failed in the critical role of providing the kingdom and people of Castile with a just and moral center. Even the bedrock of Catholicism, as embodied by old Christians, was crumbling at its very foundations. Politics and religion were conflated, and in fact, inseparable. Social and spiritual law and order had broken down.

Against this backdrop, the expectations for Isabel were clear. The immediate and tangible task that presented itself was the restoration of order in the realm. She achieved this in a variety of ways. In an attempt to restore social and political order to the realm the monarchs revived the medieval institution of the hermandades or brotherhoods. In their re-founded form these were intended as police forces and judicial tribunals. Most significantly, they answered to and took direction from the crown and not local officials. ${ }^{34}$

To answer the cry of dwindling devotion and impiety, Ferdinand and Isabel revived the papal inquisition and placed it under the direct control of the Spanish crown in order to root out the unfaithful and heretical - a decision which Valera applauded. The initial target of the institution was the anxiety-producing converso population that was suspected of crypto-Judaism. Given his earlier criticisms, it is not surprising, then, that Valera

${ }^{33}$ Ibid., 87.

${ }^{34}$ Lunenfeld provides a more extensive study of this institution. 
applauded this decision (122-24). In fact, Valera's praise for all of these actions flowed freely: "Who could believe that kingdoms so long ruled by a tyrannical and excessively greedy government ... could be restored to peace and harmony and justice in so short a time?" (6). In a different work he continued to underscore Isabel's legitimacy by highlighting her power to restore Spain: "just as our Lord wished that our glorious Lady might be born in this world because from her would proceed the Universal Redeemer of the human lineage, so he determined that you, My Lady, would be born to reform and restore these kingdoms and lead them out from the tyrannical government under which they have been for so long." 35

Apocalyptic sentiments of this type often welcomed the rise of monarchs to the throne in late-medieval and Renaissance Europe, but in Spain these took on tangible meaning for a society that had been poised for and engaged in the Christian reconquest of Muslim occupation of the peninsula for over five hundred years. Each successive king was greeted with the expectation that he would restore the entire peninsula to unified Christian rule. Success in this arena was a measure of a strong monarchy. Enrique had not met this challenge in the eyes of many of his critics. ${ }^{36}$ Chief among the criticisms of his campaign were his unwillingness to lay waste to the countryside and his reluctance to attack the city of Granada directly and definitively. ${ }^{37}$ Isabel would learn from Enrique's mistakes.

Enrique's perceived failures in the attacks on Muslim Spain only heightened the prophetic pronouncements that Isabel would triumph and deliver Spain into a golden age heralded by the defeat of Granada. Although it would be Ferdinand leading the troops into battle, the royal couple's chroniclers portrayed the campaign as Isabel's war: "By the solicitude of this Queen was begun, and by her diligence was continued, the war against the Moors, until all the kingdom of Granada was won."38 Though she certainly could not march onto the battlefield, Isabel made her presence known, often making camp in the south of Spain during the war. When Ferdinand advised a temporary cessation to the Granada campaign in order to turn attention to the border with France, she told him he could remain in Aragon to meet those

${ }^{35}$ Quoted in Liss, 157.

${ }^{36}$ For an interpretation of Enrique's campaign in Granada that draws out its positive features see Phillips, 54-56. Although Enrique may certainly fare better under the more flattering light of modern historical analysis, it is, again, perception (manufactured or otherwise) that mattered in establishing Isabel's political legitimacy. And the perception was that Enrique had not done all that he could in restoring the region of Granada to Christian rule.

${ }^{37}$ Valera, 127.

${ }^{38}$ Quoted in Liss, 194. 
challenges, but the war in the south would continue. ${ }^{39}$ She appeared before the troops and even rode with them at the start of individual campaigns. ${ }^{40}$

Yet this was not a war waged simply in the name of prowess on the field of battle. It was, of course, a just and holy war, financed in part by revenues approved by the papacy. It was not enough, then, for Spain to triumph militarily. A complete victory would renew Spain religiously as well. Thus, for example, mosques taken in battle were sanctified as churches. Ultimately, of course, Isabel and Ferdinand achieved what no other Spanish monarchs before them had: they successfully rid the peninsula of the Muslim territorial presence with their decisive victory in Granada. Isabel's reputation was amply rewarded for all of her efforts. Victory in Granada fulfilled the prophecy that attended her rise to the throne. What had been unattainable for Enrique had been successfully achieved by Isabel; in a description laden with apocalyptic significance, she was, according to Pulgar, the "good shepherd" for whom Castile had been waiting $(1929,224)$.

Having addressed the peninsula's anxieties about the presence of Jews, Muslims, and conversos, Isabel turned her attention to putting the house of Spanish Catholicism in order. Many believed that Spain had fallen from favor due to its lapsed state of religious affairs. Valera's comments had, of course, been quite revealing. Under the reign of Enrique IV not only recent converts to Catholicism were lapsing, so, too, were old Christians. ${ }^{41}$ Isabel and Ferdinand sought to address this concern through a thorough reform of Spanish clergy. ${ }^{42}$ Regular and secular religious were expected to provide the laity with exemplary models of piety and devotion. These included adhering to a recognized code of discipline and fulfilling their spiritual and liturgical responsibilities. Isabel and Ferdinand quickly found that the behavior of Spain's religious did not meet the demands of such expectations.

Due to their particular relationship to the virtues of virginity and chastity, religious women came to occupy a distinct place in this reform. Much as Isabel's female nature threatened the stability of the Spanish throne, so, too, the sexuality, even of women who had taken religious vows, threatened the integrity of Spanish Catholicism, and by association, Isabel's redemptive mission. The critical nature of female chastity to the reform campaign quickly revealed itself in the insistence that nuns, but not necessarily monks, observe strict claustration. The late-fourteenth and early-fifteenth centuries had actually seen a revival of the ideal of male monastic enclosure under the

\footnotetext{
${ }^{39}$ Ibid., 202.

${ }^{40}$ Ibid., 213.

${ }^{41}$ See Valera, 123.

${ }^{42}$ For a discussion of these campaigns see Bilinkoff, García Oro, Nalle, Olin.
} 
guidance of the monastery of San Benito in Valladolid. ${ }^{43}$ This community, founded in 1390, had become a reforming powerhouse whose model of monastic discipline, which included enclosure, had been disseminated throughout the peninsula with the foundation of member houses and the reform of existing communities. ${ }^{44}$

By the late fifteenth century, however, the Spanish monarchs returned the primary focus to female enclosure. The monarchs had received two papal bulls to authorize their reform of Spain's religious orders. One, Quanta in Dei Ecclesia (1493), procured in response to the Spanish envoys' reports of the dissolute life of male and female monastics, allowed their ecclesiastical visitors to visit both male and female houses. The second, Exposuerunt nobis (also issued in 1493), was directed at the state of affairs in female houses and specifically empowered the visitors not simply to visit, but to alter the lifestyle of the nuns within these houses as they saw fit. ${ }^{45}$ It was with this provision that the reformers were able to introduce strict claustration to female houses. In the eyes of these reformers nuns walked a tenuous line between embodying the enormous moral potential necessary to fulfill the observance of virginity or chastity, and being female and thereby incapable of protecting these same virtues on their own. They required the protection of enclosure to ensure that these virtues would remain uncorrupted. The protection of virtue also made it possible for the nuns to perform their spiritual duties responsibly. Claustration ensured that they would not be distracted from their prayers and that these prayers would not be tainted by contact with the temporal world. That such lapses were possible was suggested by Ambrosio Montesino who wrote: "Isn't it useless to lock up the nuns' cloistered bodies, when their thoughts are in the courts and towns?" 46

In a series of dispatches detailing the means by which ecclesiastical visitors were supposed to insure the observance of enclosure, the monarchs and their reformers continued to articulate their ideology of female purity and

${ }^{43}$ This despite the fact that by this time male monastic enclosure was infrequent in Spain and was rather an ideal expected primarily of female monastics. In this, Spain was in step with prevailing European trends in monastic claustration; see McLaughlin; Schulenberg. See also the Dictionnaire de spiritualité, ascétique, et mystique, "Clôture," that asserts that "In male monasteries, strict enclosure, that is to say the prohibition of leaving the monastery, is an uncommon occurrence." It finds instead that in female houses it becomes a "general rule." The novelty of male enclosure is further underscored by the entry's assertion that the community at San Benito in Valladolid is one of only a handful of examples of male monastic enclosure.

${ }^{44}$ For a further exploration of male and female claustration in late-medieval Spain see Lehfeldt.

${ }^{45}$ García Oro, 46-49.

${ }^{46}$ Cited in Daichman, 55-56. 
chastity. The language of these indicates that enclosure sought the ordering of the physical space of the convents in such a way that sensory contact with the outside world would be severely limited. Aside from simply insisting that the nuns not leave the convent (active enclosure) and that the entrance of other individuals, even confessors and other clerics, be strictly monitored (passive enclosure), structural specifications were also detailed. A dispatch of 1493 sent by Isabel and Ferdinand to local authorities in Barcelona, for example, instructed that doors and windows could not look onto the street and that the abbess was to control the keys to them. ${ }^{47}$ The instructions given to Santa Clara of Barcelona by the reforming visitors required, among other things, that they construct a wall in their garden to separate the convent from neighboring houses. ${ }^{48}$ They were also directed to hang black curtains in the grilles of the choir and visiting room (locutorio), and to construct a revolving window (torno) for the visiting room. ${ }^{49}$ These measures would limit the contact between the nuns and the temptations of the temporal world, thus limiting the potential for immoral behavior. Generalized temptations could threaten the vow of chastity, for as Caesarius of Arles (470-542) had articulated in his rule for nuns, a lack of enclosure would allow nuns to "hear what is not proper, or say what is not fitting, or see what could be injurious to chastity." 50

Thus, for example, the rule of the Concepcionist Order also included a chapter addressing the need for enclosure. ${ }^{51}$ The abbess was not allowed to let anyone, secular or religious, enter the "intrinsic enclosure" of the house. Those with the proper ecclesiastical license could enter. Having entered, however, they could not move through the house or speak with members of the foundation unless in the presence of at least two or three other nuns.

Isabel's religious advisor and confessor, Talavera (author of the Advent sermon about the eagle), offered an additional model of enclosure to the Cistercian nuns of Santa Ana in Avila - a model which some have suggested embodied his vision for religious reform throughout the peninsula. ${ }^{52}$ This text, however, is significant because it joined the anxiety about female sexuality inherent in demands of claustration with Spain's anxiety over religious and ethnic purity. In this context, he invoked language that suggested

${ }^{47}$ García Oro, 103.

${ }^{48}$ Azcona, 1957, 11.

${ }^{49}$ Ibid., 12-13.

${ }^{50}$ Quoted in Schulenberg, 54.

${ }^{51}$ For the Concepcionist Rule see Meseguer Fernández, 1965.

${ }^{52} \mathrm{~A}$ transcription of Talavera's rule "De como han de vivir las monjas de San Bernardo en sus monasterios en Avila," appears in González Hernández, 143-74. See also the comments of Azcona, 1964, 576. 
a connection between sexual purity and ethnic purity. Talavera included in his definition of enclosure "the things that are helpful in guarding the purity of chastity" (las cosas que aprovechan para guardar la limpieza de castidad). ${ }^{53}$ Talavera underscored the concept of limpieza when he urged the nuns to "flee with hatred those things that could taint/stain and bring infamy to their purity and perfect chastity" [Huid hermanas con mucho estudio y aborrecimiento todas las cosas que pueden macular y traer infamia a vuestra limpieza y perfecta castidad].

Talavera's use of the words "limpieza" and "macular" is critical in the context of the contested place of converso and Jewish minorities in late-medieval Castile. Although Isabel and Ferdinand had not yet endorsed the concept of limpieza de sangre (purity of blood; which referred to a lineage free of Jewish or Moorish blood) - baptism of Jews, for example, could still be evidence of a true conversion - the notion had already circulated widely in Spain. ${ }^{54}$ Spaniards in the fifteenth century seemed increasingly preoccupied with this concept. ${ }^{55}$ The city of Toledo had passed the first statute of limpieza de sangre in 1449 which banned conversos from holding important public offices. ${ }^{56}$ Various religious orders in Spain had contemplated applying similar statutes to their memberships (some orders would eventually institute such measures). At the heart of these statutes was the suspicion that even converts to Christianity might relapse and begin Judaizing, thus threatening the health and integrity of the Christian community. By the early 1490 s when Talavera probably drafted this rule, the climate was increasingly tense. As we have already seen, for example, the initial target of the Inquisition was conversos.

Thus, Talavera's words seem carefully chosen. Purity for Talavera was embodied in the loaded term "limpieza," which evoked images of an unassailable cleanliness, free of pollutants. To denote taint or stain Talavera used the verb "macular" which was also laden with significance in a religious culture that looked to the Virgin Mary as In-maculada, without taint, thus signifying her lack of complicity in original sin. Conversos were even sometimes called "maculados." 57 Old Christians, in contrast, were called "cristianos limpios." 58 If "limpieza de sangre" suggested an ethnically pure

${ }^{53}$ Emphasis mine.

${ }^{54}$ Sicroff.

${ }^{55}$ Sicroff suggests that these types of measures built on the increasing hostility to Jews in Spain as evidenced in the pogroms of 1391.

${ }^{56}$ Sicroff, 54-55.

${ }^{57}$ Ibid., 43.

${ }^{58}$ Ibid., 44. 
blood line, then conversos were doubly-marked by their taint or "macula." They could not claim a pure Christian blood line and this impurity meant that they could never - even if converted - fully enjoy the redemptive message of doctrines like the Immaculate Conception. Talavera's theology of enclosure, therefore, was a culturally resonant and potent marriage of images of sexual and ethnic purity. Isabel's support of such models emphasizes the centrality of sexual and ethnic purity to her campaign for political legitimacy. Claustration protected sexual purity. As such admonitions to enclosure were caught up in dual characterizations of women - even religious women - as dangerous seductresses and as women susceptible to the seductions of others. Isabel had learned the lessons embodied in texts like the Jardin de las nobles doncellas all too well. Even though she had spent her tenure on the throne seeking to rise above stereotypical characterizations of women as both more dangerous and weaker than men, she expected no more of the religious women of her kingdom. Talavera's further reliance on the imagery of purity and pollutants suggested that Christianity was only truly safe when it was not only sexually uncorrupted, but also ethnically pure - a notion Isabel had supported in her reconquest of Granada and use of the Inquisition against conversos.

In her various reforms and campaigns, then, Isabel had addressed many of the concerns that had plagued Enrique. Yet although Isabel had restored the social and religious order in ways that had eluded him, she still had to fashion an acceptable image of her sexuality in order to further substantiate her political legitimacy. As in earlier cases, the theme of redemption would work to her advantage. Yet less ambivalent success (than that offered by the texts of Córdoba and Talavera) in advancing the cause of redemption would, in fact, come from the identification of Isabel with overtly female symbols of renewal and promise. The most profound example of this was the ever-increasing parallels drawn between Isabel and the Virgin Mary, particularly the doctrine of her Immaculate Conception.

Isabel was supposed to be a strong ruler and yet she was confined to a female body. Her matrimonial ties to Ferdinand softened some of the blow associated with a woman on the Spanish throne and as we have already seen, while she may have bowed to his husbandly authority in private, her public rule was forthright and unapologetic. The bearing of children (and she would give birth to five) provided an acceptable outlet for her womanly nature. Yet her role as wife and mother also placed her fundamentally sexual nature on display. Both roles would have been perfectly acceptable had Isabel not also been sitting on the throne of Castile. The mere presence of a female body in the position of monarch could corrupt and thus threaten the health of the realm. Particularly during her pregnancies (and Isabel does not 
seem to have observed periods of confinement while pregnant), ${ }^{59}$ her kingdom was provided with ready evidence of Isabel's complicity in the sins of Eve. Unlike Elizabeth I of England she could not disavow marriage and motherhood thereby creating a less sexualized presence. ${ }^{60}$

The task, then, was to align these roles with metaphorical images that would underscore Isabel's political legitimacy. Like Elizabeth I later in the sixteenth century, Isabel and her advisors drew primarily on an identification with the Virgin Mary. Where Elizabeth could draw parallels between her chaste sexual nature and Mary's virginity, however, Isabel's case was more complicated. Isabel's identification with the Virgin Mary would, in fact, exploit the Virgin's ambiguous sexuality and emphasize its redemptive messages.

To begin with, Mary was the theological antidote to Eve. She redeemed the sins of Eve; she triumphed "where the first Eve failed." ${ }^{\prime 1}$ One of Isabel's favorite poets, fray Iñigo de Mendoza wrote that she had come by the grace of God to rescue the people whose lives had been lost by the sin of "una muger," which is to say, Eve. ${ }^{62}$ By the twelfth century theologians had drawn parallels between the Virgin and a woman prophesied in the Book of Genesis: "I will put enmities between thee and the woman, and thy seed and her seed: she shall crush thy head, and thou shalt lie in wait for her heel." ${ }^{63}$ This portrayal of the woman crushing the serpent's head was the promised redemption offered by Mary. Isabel's association with this image mitigated her sexuality and her bearing of Eve's punishment of the pains of childbirth. Yet childbirth could, properly modeled and fashioned, also be redemptive. Although she had already given birth to a daughter, Juana, in 1470, a greater outpouring of enthusiasm greeted the birth of Isabel's first son, Juan, in 1478. With this act, Isabel, in the eyes of her chroniclers and contemporaries, delivered Spain into the long-promised Golden Age. She had provided a male heir to the throne. Here the parallels with the Virgin were obvious. Mary had offered the world the ultimate redemption: the son of God. Isabel offered a similar redemption. She gave Castile an indisputable male heir

${ }^{59}$ I am grateful to Katherine Swett for raising the question of whether or not Isabel confined herself during her pregnancies.

${ }^{60}$ Marriage and motherhood were, of course, double-edged swords for female rulers of the period. Elizabeth I of England, for her part, was amply criticized for not taking a husband and producing heirs. See Levin and Hackett.

${ }^{61}$ Warner, 245.

${ }^{62}$ Pulgar, $1971,75-76$. This quotation comes from a poem by Iñigo de Mendoza appended by Tate to his edition of Pulgar's Claros varones.

${ }^{63} \mathrm{Cited}$ in Warner, 245. Later biblical scholars would find that in St. Jerome's translation the "she" was, in fact, an inaccurate referent. The pronoun referred instead to an "it," the seed itself. Nonetheless, this association persisted through the medieval and early modern periods. 
who stood in a direct line to the throne. Pulgar suggested that God had chosen Isabel especially, rather than seeking the succession of the throne in either the offspring of Enrique or Alfonso (Isabel's brother who had died in 1468).$^{64}$ In this Isabel had redeemed the ultimate imperfection of her own ascendance to the throne: the lack of a male heir.

Yet just as Mary's human role in Christ's birth raised questions for some about her sinful nature and cast doubt on her purity, so, too, Isabel's redemptive powers in bringing forth a human son who would act as Spain's savior, seemed potentially compromised. Mary, despite her participation in the birth of the Savior, had been granted virginal status. Hers was a conception free from the sin of sexual intercourse. From the days of the early church, however, debate surrounded Mary's concupiscence or participation in original sin. Mary needed to be preserved from all sin in order to be "the sole proper instrument by which God became man." "Although a subject of controversy into the nineteenth century before it was resolved by the papal bull Ineffabilis Deus, the resolution was the doctrine of the Immaculate Conception, according to which Mary was free from the burden of sin and sinful desires. ${ }^{66}$

Spanish intellectuals would offer a similar solution for Isabel. Her redemptive role would be likened to Mary's and although Isabel of course remained fully human, parallels were drawn between her purity and the Immaculate Conception. ${ }^{67}$ Devotion to the doctrine of the Immaculate Conception was particularly enthusiastic in Spain in the late Middle Ages and Renaissance. It seems to have been cultivated most prodigiously first in Aragon and Barcelona, owing largely to its championing by the famous mystic Ramón Lull. ${ }^{68}$ Throughout Europe it was a doctrine cultivated by the Franciscan Immaculists against the claims of the Dominican Maculists. The eventual predominance and power of St. Francis's order in Spain allowed the doctrine to gain in strength and popularity. ${ }^{69}$ Familiarity with its iconography and metaphorical images, then, had amply prepared Isabel's chroniclers and poets to draw the necessary comparisons. Although Isabel herself would

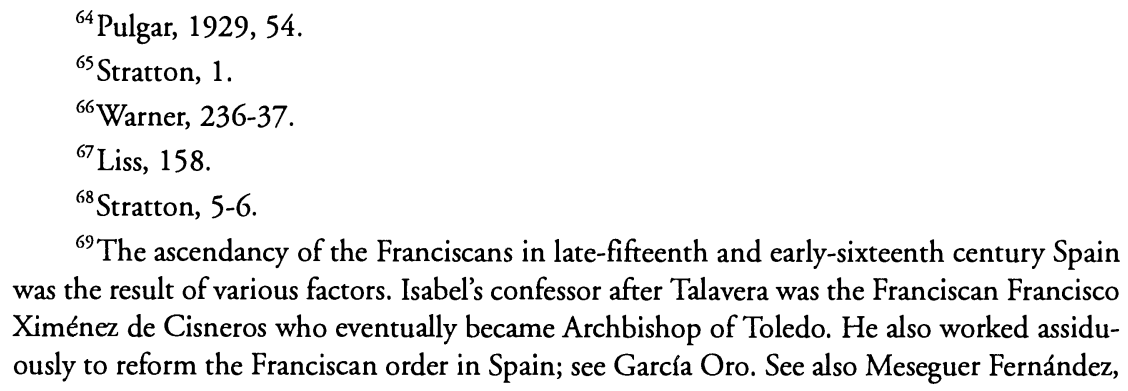

${ }^{69}$ The ascendancy of the Franciscans in late-fifteenth and early-sixteenth century Spain was the result of various factors. Isabel's confessor after Talavera was the Franciscan Francisco Ximénez de Cisneros who eventually became Archbishop of Toledo. He also worked assiduously to reform the Franciscan order in Spain; see García Oro. See also Meseguer Fernández, 1959. 
never be artistically represented according to the iconography of the doctrine, her courtiers made numerous references to the message of this doctrine. ${ }^{70}$

Comparisons that likened Isabel's role to that of Mary's in offering the redemption of Eve's sins, for example, may have been Immaculist in their intent since this image was used in the fifteenth century to represent the doctrine. ${ }^{71}$ Thus, Iñigo de Mendoza's verse dedicated to Isabel, and perhaps intended to invoke parallels between Isabel and Mary, begins with a description of Mary's exalted status as "the noble, illustrious Queen" that came by the grace of God to redeem humankind. ${ }^{72}$ Isabel also offered her patronage to the poet and cleric, Ambrosio de Montesino, a Franciscan champion of Immaculist theology. ${ }^{73}$ In his poetry, Montesino sang the praises of the immaculately conceived Virgin's "pureza original" which made the miracle of her ability to redeem the sins of Eve all the more awe-inspiring. ${ }^{74}$

A further identification of Isabel with Mary and the doctrine of her Immaculate Conception was also redemptive in its meaning. In this instance, the image was that of the Woman of the Apocalypse of whom it was written in the Book of Revelation: "And a great sign appeared in heaven: a Woman clothed in the sun, and the moon was beneath her feet, and upon her head a crown of 12 stars." 75 The woman was often portrayed carrying a child in keeping with the verses which followed the initial appearance of the woman: "And she brought forth a manchild, who was to rule all nations." 76 The image from Genesis was also revived in depictions of the apocalyptic woman crushing a serpent underfoot. Perhaps because both carried a redemptive message, by the late fifteenth century the image of this woman and that of the Immaculate Conception had been conflated in works of art within the Concepcionist order. ${ }^{77}$ Isabel was already identified with the Immaculate

${ }^{70}$ There is some difficulty in distinguishing between depictions of the Virgin Mary and images of her intended to illustrate the doctrine of the Immaculate Conception in fifteenth-century Spain since this was a period in which artistic representations of the doctrine were still being worked out. See the comments of Stratton, 5-34 and Levi d'Ancona, 15-19. Both authors emphasize the necessity of investigating the artist, commission, and other factors to determine whether or not an Immaculist program is intended.

${ }^{71}$ Levi d'Ancona, 35-36.

${ }^{72}$ Pulgar, 1971, 75-76.

${ }^{73}$ Alvarez Pellitero, 120-25.

${ }^{74}$ Ibid., 121.

${ }^{75}$ Cited in Liss, 159.

${ }^{76}$ Cited in Stratton, 48.

${ }^{77} \mathrm{Liss}, 160$. For an interpretation that finds evidence of this conflation in the visual arts coming at a later date, see Stratton, 46-58. Even if a conflation of these images did not occur as early as Liss finds them, the identification of Isabel with each of these images is certain. 
Conception; in the religious culture of Spain at the time, it was a logical step to associate her with this figure as well. Like the Woman of the Apocalypse she was a redemptive figure who had brought forth a male child. Further, an association with the apocalyptic sentiments of this figure served to emphasize the eschatological significance of the rule of Isabel.

There is also ample evidence to suggest that Isabel was an enthusiastic patron of this doctrine. She was perhaps encouraged to propagate its spread in Castile as a result of Ferdinand's Aragonese ties since its strength in the peninsula had begun in that region. ${ }^{78}$ In 1477 she granted a generous stipend to the Jeronymite monks at Guadalupe in order that they might adequately celebrate the feast of the Immaculate Conception (December 8) each year. ${ }^{79}$ She also offered patronage to literary figures who upheld and glorified the doctrine. ${ }^{80}$ These included the work of a Spanish nun, Isabel de Villena, whose Vita Christi included an extended treatment of the Virgin's Immaculate Conception. The most striking evidence of Isabel's endorsement of the doctrine was her support of a female branch of the Franciscan order, the Concepcionists. The order had been founded in 1489 in Toledo by a Benedictine nun, Beatriz de Silva. Beatriz had consecrated her life to the Virgin who had appeared to her and entrusted her with the task of making a foundation that would honor the Virgin. As early as around 1477 she discussed her plans for an order dedicated to the Immaculate Conception of Mary with Isabel, Talavera, and Cardinal Mendoza. By 1494 the Concepcionist order had been incorporated into the Franciscan order, thereby placing it under the rule of Saint Clare.

Her support of this order underscored Isabel's support of a doctrine whose meaning transcended the realm of the religious and became a political bolster to her reign. By subsuming her sexuality in the metaphorical power of the doctrine of the Immaculate Conception, Isabel was able to provide sanction for her womanly nature. She was married and had borne children, but neither of these things compromised her ability to rule provided that she was identified with the purity and sinlessness of this doctrine. The kingdom would not be corrupted by Isabel's female nature.

Isabel died in 1504 leaving behind for historians a complex picture of the intersection of gender, sexuality, and politics during this period of Spanish history. Sexuality and gender had taught Isabel some curious lessons while she occupied the throne. Most importantly she had learned that as the measure of the career of a ruler, both were flexible yardsticks that varied ac-

\footnotetext{
${ }^{78}$ See Stratton, 8-9 for a brief discussion of Ferdinand's support of the doctrine.

${ }^{79}$ Ibid., 9.

${ }^{80} \mathrm{Ibid}$
} 
cording to circumstance. Her success in manipulating these categories rested on her ability to preserve the integrity of the peninsula and Spanish Catholicism in ways that had supposedly eluded her unfortunate half-brother, Enrique. To do so, she had to assert an image of strength and purity. Her ability to produce a male heir, for example, was a powerful use of her sexuality that testified to her strength as a ruler. Lest her carnality be celebrated in and of itself, however, she was allied with the sexually pure figure of the Virgin Mary, thereby "packaging" her sexuality in acceptable terms. When these images of sexual purity were linked to ethnic purity, the mix became that much more powerful. Enrique's perceived "soft" stance on conversos, Jews, and Muslims, for example, had ultimately been used by his detractors to effeminize him. Isabel countered this with a series of strong responses: the reconquest of Granada, the expulsion of the Jews, and the oversight of an Inquisition that tried conversos. Yet power had to be carefully employed. Even those who were Isabel's partisans drafted advice to her in such a way that she was encouraged to transcend her gender or to hide her obvious power behind things like wifely obedience. Isabel may have been early modern Europe's first female monarch, but she was also thus the first to learn about and incorporate into her own decisions the complex negotiations that made female rule during this period possible.

Cleveland State University 


\section{Bibliography}

Alvarez Pellitero, Ana María. 1976. La obra lingüistica y literaria de fray Ambrosio Montesino. Valladolid.

Amador de los Ríos, José. 1865. Historia critica de la literature española. Vol. 7. Madrid.

Azcona, Tarsicio de. 1957. "Reforma de las clarisas de Cataluña en tiempo de los Reyes Católicos." Collectanea Franciscana 27: 5-51.

1964. Isabel la Católica: estudio critico de su vida y su reinado. Madrid.

Baldwin, Spurgeon, ed. 1982. The Medieval Castilian Bestiary. Exeter.

Bilinkoff, Jodi. 1989. The Avila of Saint Teresa: Religious Reform in a Sixteenth-Century City. Ithaca.

Brandes, Stanley. 1990. Metaphors of Masculinity: Sex and Status in Andalusian Folklore. Philadelphia.

Bullough, Vern L. 1973. "Medieval Medical and Scientific Views of Women." Viator 4: 492-501.

Cadden, Joan. 1993. Meanings of Sex Differences in the Middle Ages: Medicine, Science, and Culture. Cambridge.

Córdoba, Martín de. 1974. Jardín de las nobles doncellas: a critical edition and study. Ed. Harriet Goldberg. Chapel Hill.

Crónica incompleta de los Reyes Católicos (1469-1476). 1934. Ed. Julio Puyol. Madrid.

Daichman, Graciela. 1986. Wayward Nuns in Medieval Literature. Syracuse.

Dictionnaire de spiritualité, ascétique, et mystique. 1937. Paris.

Fradenburg, Louise Olga. 1992. Women and Sovereignty. Edinburgh.

García Oro, José. 1971. Cisneros y la reforma del clero español en tiempo de los Reyes Católicos. Madrid.

González Hernández, Olegario. 1960. "Fray Hernando de Talavera: un aspecto nuevo de su personalidad." Hispania Sacra 13: 143-74.
Hackett, Helen. 1995. Virgin Mother, Maiden Queen: Elizabeth I and the Cult of the Virgin Mary. New York.

Lehfeldt, Elizabeth A. 1996. "Sacred and Secular Spaces: Religious Women in Golden-Age Valladolid, Spain." Ph.D. diss., Indiana University.

Levi d'Ancona, Mirella. 1957. The Iconography of the Immaculate Conception in the Middle Ages and Early Renaissance. New York.

Levin, Carole. 1994. The Heart and Stomach of a King: Elizabeth I and the Politics of Sex and Power. Philadelphia.

Liss, Peggy K. 1992. Isabel the Queen: Life and Times. New York.

Lunenfeld, Marvin. 1970. The Council of the Santa Hermandad: A Study of the Pacification Forces of Ferdinand and Isabella. Coral Gables, FL.

McLaughlin, Eleanor Commo. 1974. "Equality of Souls, Inequality of Sexes: Woman in Medieval Theology." In Religion and Sexism: Images of Woman in the Jewish and Christian Traditions, ed. Rosemary Ruether, 213-66. New York.

Meseguer Fernández, Juan. 1959. "Franciscanismo de Isabel la Católica." Archivo Ibero-Americano 19: 153-95.

1965. "Primeras constituciones de las Franciscanas Concepcionistas." Archivo Ibero-Americano 100: 1-29.

Mirrer, Louise. 1996. Women, Jews, and Muslims in the Texts of Reconquest Castile. Ann Arbor.

Nalle, Sara T. 1992. God in La Mancha: Religious Reform and the People of Cuenca, 1500-1650. Baltimore.

Olin, John C. 1990. Catholic Reform from Cardinal Ximenes to the Council of Trent, 1495-1563. New York.

Ornstein, Jacob. 1942. "Misogyny and Pro-Feminism in Early Castilian Literature." Modern Language Quarterly 3: 221-34. 
Phillips, William D., Jr. 1978. Enrique IV and the Crisis of Castile. Cambridge, MA.

Pulgar, Fernando de. 1929. Letras. Glosa a las "Coplas de Mingo Revulgo." Ed. J. Domínguez Bordona. Madrid. 1943. Crónica de los Reyes Católicos. Ed. Juan de Mata Carriazo. 2 vols. Madrid.

- 1971. Claros Varones de Castilla. Ed. Robert Tate Brian. Oxford.

Ruiz, Teofilo. 1992. "Unsacred Monarchy: the Kings of Castile in the Late Middle Ages." In The City and the Realm: Burgos and Castile, 1080-1492, 10944. London.

Schulenberg, Jane Tibbetts. 1984. "Strict Active Enclosure and Its Effects on the Female Monastic Experience (ca. 500-1100)." In Distant Echoes: Medieval Religious Women, vol. 1, ed. John A. Nichols and Lillian Thomas Shank, 51-86. Kalamazoo.

Sicroff, Albert A. 1985. Los estatuos de Limpieza de Sangre: controversias entre los siglos XV y XVII. Trans. Mauro Armiño. Madrid.
Stratton, Suzanne L. 1994. The Immaculate Conception in Spanish Art. Cambridge. Surtz, Ronald. 1995. Writing Women in Late Medieval and Early Modern Spain. Philadelphia.

Valera, Diego de. 1927. Crónica de los Reyes Católicos. Ed. Juan de Mata Carriazo. Madrid.

Warner, Marina. 1976. Alone of All Her Sex: the Myth and the Cult of the Virgin Mary. New York.

Weissberger, Barbara. 1998. "Me atrevo a escribir asf': Confessional Politics in the Letters of Isabel I and Hernando de Talavera." In Women at Work in Spain: from the Middle Ages to the Early Modern Times, ed. Marilyn Stone and Carmen Benito-Vessels, 147-69. New York.

. 1999. “'A tierra, puto!': Alfonso de Palencia's Discourse of Effeminacy." In Queer Iberia: Crossing Cultures, Crossing Sexualities, ed. Gregory Hutcheson and Josiah Blackmore, 291-324. Durham, NC.

White, T. H., ed. 1954. The Book of Beasts. New York. 